Bu makaleye atıfta bulunmak için/To cite this article:

ÖZDAĞOĞLU, A. KELES, M. K. GENC, V. (2021). FUCOM ve PROMETHEE Yöntemleri ile Ticari Araç Seçimi:

Peyzaj Firmasında Bir Uygulama. Atatürk Üniversitesi Sosyal Bilimler Enstitüsü Dergisi, 25 (Özel Sayı), 231253.

\title{
FUCOM ve PROMETHEE Yöntemleri ile Ticari Araç Seçimi: Peyzaj Firmasında Bir Uygulama
}

\author{
Aşkın $\ddot{O Z} D A \breve{G} O \breve{G} L U^{(*)}$ \\ Murat Kemal KELES ${ }^{(* *)}$ \\ Volkan $G E N C^{(* *)}$
}

\begin{abstract}
Öz: İ̧sletmeler, faaliyet gösterdikleri iş alanına göre ulaşımda, mamul, yük ve eşya taşımasında çeşitli vasitalar kullanmaktadırlar. Kamyonet de işletmenin ticari anlamda kullandı ̆̆ vasıtalardan biridir. Piyasada çok çeşitli marka ve modelde kamyonet satışa sunulmaktadır. Piyasada satışa sunulan kamyonet alternatifleri de kendi aralarında farklı model ve özelliklere sahiptirler. Kamyonet alternatiflerinin fazla olması ve karar vermede çok sayıla faktörün etkili olması nedeniyle kamyonet satın alma problemi çok kriterli karar verme problemi olarak nitelendirilebilir. Bu çalışmada peyzaj sektöründe faaliyet gösteren bir firma için en uygun kamyonet seçimi problemi ele alınmıştır. Firma yetkilisi ile yapılan görüşmede, satın alınması düşünülen kamyonet için "motor tork", "servis yedek parça yaygınliğl”, "dönüş çapı" ve "istihap haddi" olmak üzere dört faktör belirlenmiştir. Bu faktörler dikkate alınarak üç kamyonet alternatifi değerlendirilmiştir. Değerlendirme kriterlerinin önem dereceleri FUCOM yöntemi ile bulunmuştur. PROMETHEE yöntemi ile de üç kamyonet arasından peyzaj firması için en uygun olanı seçilmiştir. Yapılan analiz sonuçlarına göre ticari kamyonet seçiminde "servis yedek parça yaygınlığ $\iota "$ kriteri en önemli kriter olurken, "Alternatif B" kamyoneti de en uygun kamyonet olarak belirlenmiștir.
\end{abstract}

Anahtar Kelimeler: Ticari araç seçimi, çok kriterli karar verme, FUCOM, PROMETHEE.

\section{Commercial Vehicle Selection with FUCOM and PROMETHEE Methods: An Application in Landscape Company}

\footnotetext{
Abstract: Enterprises use various vehicles in transportation of goods according to their business activities. The van is one of the vehicles used by the business commercially. Vans of various brands and models are offered for sale in the market. The van alternatives offered for sale in the market also have different models and features among themselves. Due to the fact that there are many pickup alternatives and many factors are effective in decision making, pickup problem can be described as multi-criteria decision making problem. In this study, the problem of choosing

*) Doç. Dr., Dokuz Eylül Üniversitesi İşletme Fakültesi İşletme Bölümü Üretim Yönetimi ve Pazarlama Anabilim Dalı (e-posta: askin.ozdagoglu@deu.edu.tr) (D) ORCID ID. https://orcid.org/0000-0001-5299-0622

**) Dr. Öğr. Üyesi, Isparta Uygulamalı Bilimler Üniversitesi Keçiborlu Meslek Yüksekokulu Ulaştırma Hizmetleri Bölümü (e-posta: muratkeles@isparta.edu.tr) (D) ORCID ID. https://orcid.org/0000-0003-0374-6839

$\left.{ }^{* * *}\right)$ Doktora Öğrencisi, Dokuz Eylül Üniversitesi Sosyal Bilimler Enstitüsü İngilizce İşletme Bölümü (e-posta: volkangenc@yandex.com) (D) ORCID ID. https://orcid.org/0000-0003-2184$482 \mathrm{X}$

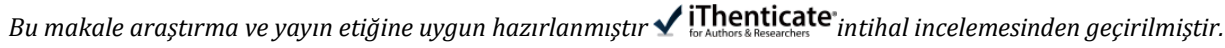




\section{Așkın ÖZDA $\breve{G} \breve{G} L U$ \\ 232 Murat Kemal KELES Volkan GENC}

A T A S OBED

202125 (Özel Sayı): 231-253

the most suitable truck for a company operating in the landscape sector is discussed. During the meeting with the company representative, four factors were determined for the pickup truck, namely "engine torque", "service spare part prevalence", "turning diameter" and "loading limit". Considering these factors, three truck alternatives were evaluated. Significance levels of evaluation criteria were found by FUCOM method. With the PROMETHEE method, the most suitable van for the landscape firm was chosen among the three vans. According to the results of the analysis, "service spare part prevalence" was the most important criterion in the selection of commercial pickup trucks, while the "Alternative B" pickup truck was determined as the most suitable pickup truck.

Keywords: Commercial vehicle selection, multi criteria decision making, FUCOM, PROMETHEE.

Makale Geliş Tarihi: 14.11.2020

Makale Kabul Tarihi: 14.11.2021

DOI:10.53487/ataunisosbil.825910

\section{Giriş}

Ülkemizde yük ve yolcu taşımak için kullanılan araçlar genelde ticari araç olarak adlandırılmaktadır. Bu araçlar kendi bünyesinde taşıdığ 1 yük ve yolcu miktarına göre ağır ticari ve hafif ticari olarak sınıflandırılmaktadır. Günümüzde peyzaj sektöründe faaliyet gösteren bir firmanın, bir ticari işletme olarak, iç ve dış süs bitkilerinin günlük nakliye ve teslimat işlerinde kullanmak üzere hafif ticari segmentte bulunan bir araca ihtiyacı olmaktadır. Kullanım amacı doğrultusunda, belirlenen kriterler çerçevesinde en doğru aracın seçilmesi önemlidir.

Ticari araç seçimi, firma açısından uzun vadede oluşturduğu maliyetler bakımından ciddi bir gider kalemi teşkil etmektedir. Ticari araç alımı hususunda yanlış alınan bir karar ilgili aracın kullanım ömrü boyunca firmanın maliyetlerini doğrudan arttıracaktır. Bu konuda sadece aracın kullanımı sırasında oluşan yakıt tüketimi ve periyodik bakım giderleri gibi temel maliyet unsurları düşünülmemelidir (Byun, 2001). Örneğin, bir ticari araç nakliye sırasında arızalanır veya kazaya karışırsa, bu araç teknik servis ve yedek parça tedariki noktasında sıkıntı yaşatırsa, serviste beklediği her gün firma için nakliye bazlı dış kaynak kullanımını zorunlu kılacağı için ciddi bir gider kalemi oluşturacaktır. Firmalar açısından rekabetin çetin geçtiği günümüzde bu tür araçların seçiminin doğru ve isabetli bir şekilde yapılması gereklidir ve rekabet avantajı sağlanması açısından önemlidir.

Çalışmada peyzaj sektöründe faaliyet gösteren bir şahıs işletmesinin günlük işlerinde kullanacağı bir kamyonet seçimi yapılacağı için şu araştırma sorularına çözüm aranmıştır:

Araştırma sorusu 1- Çalışma kapsamındaki söz konusu şahıs işletmesinin ihtiyacı olan ticari kamyoneti seçerken hangi kriterler baz alınacaktır?

Araştırma sorusu 2- Belirlenen değerlendirme kriterlerinin önem dereceleri ne olacaktır?

Araştırma sorusu 3- Çalışma kapsamındaki söz konusu şahıs işletmesinin belirlemiş olduğu üç adet ticari kamyonetten en uygunu hangisidir? 
$\mathrm{Bu}$ çalışmanın amacı, peyzaj sektöründe faaliyet gösteren bir şahıs işletmesinin günlük işlerinde kullanmak amaciyla ihtiyaç duyduğu kamyonetin seçimidir. Kamyonet seçiminde üç farklı alternatif ve göz önüne alınan dört farklı kriter aşağıda verilmiştir. Kriterler sırası ile istihap haddi, motor tork değeri, dönüş çapı ve servis/yedek parça yaygınlığı olarak belirlenmiştir. Servis ve yedek parça bulunabilirliği, yetkili servis harici özel servis ve yedek parça satışı gerçekleştiren yerlerin sayısı tam olarak bilinemediğinden 0-100 arası puanlanmıştır. Kriterlerin seçim problemindeki etkisi FUCOM (Full Consistency Method) yöntemi ile belirlenmiştir. Alternatifler arasında seçim yapabilmek amaciyla PROMETHEE (The Preference Ranking Organization Method For Enrichment Evaluation) yöntemi kullanılmıştır. Kriterler arası herhangi bir tercih söz konusu olmadığı için PROMETHEE yöntemi kapsamında 1. Tip tercih fonksiyonu kullanılmıştır. Kamyonet seçimindeki değerlendirme kriterleri sürüş eğitmeni tarafından belirlenmiş ve karşılaştırılmıştır. Her bir alternatifin teknik kriterler açısından sahip oldukları değerler teknik kataloglardan toplanmıştır.

FUCOM yönteminin, BWM, ANP, AHP, vb. diğer ağırlıklandırma yöntemlerine göre, temel avantajları şunlardır:

- İkili karşılaştırmaları daha az yaparak sonuca ulaşması (kriter sayısının bir eksiği kadar karşılaştrmaya ihtiyaç duyması),

- Kriterlerin ikili karşılaştırmalarının tutarlı bir şekilde olmasına imkân vermesi,

- Kriter ağırlıklarının hesaplanmasının daha güvenilir şekilde olmasına olanak tanıması (Ecer, 2021a: 28).

Ayrıca, FUCOM yönteminde amaç fonksiyonun sapma değerinin en küçüklenmesi şeklinde kurulması ve amaç fonksiyon değeri sıfıra ne kadar yakın ise o kadar sağlıklı uzman değerlendirmesi olduğunu göstermesi FUCOM yönteminin diğer avantajlarındandır.

Çalışmada kullanılan diğer yöntem olan PROMETHEE'nin temel avantajı, ikili karşılaştırmalarda her bir değerlendirme kriteri için altı farklı tercih fonksiyonu arasından o kriter açısından en uygun olanının uzman görüşleri doğrultusunda belirlenebilmesidir (Behzadian vd., 2010).

Ticari araç seçimi çalışmalarında ÇKKV yöntemleri sıklıkla kullanılmaktadır. Örneğin, ÇKKV yöntemlerinden olan ve bu çalışmada da uygulanan PROMETHEE yönteminin otomobil, panelvan, ağır ticari araç seçimi gibi problemlerde kullanıldığı görülmüştür. Ancak yerli literatürde PROMETHEE yöntemiyle kamyonet seçiminin yapıldığı ve FUCOM yöntemiyle de ticari araç değerlendirme kriterlerinin ağırlığının tespit edildiği bir çalışmaya rastlanmamıştır. Bu çalışma ile FUCOM ve PROMETHEE yöntemleri bütünleşik olarak ilk kez bir ticari araç seçimi probleminde kullanılmış olacaktır. Ayrıca yerli literatürde FUCOM yönteminin kullanıldığı çalışma sayısı oldukça azdır. Bu çalışmayla FUCOM yönteminin uygulandığı bir çalışma daha yerli literatüre kazandırılacaktır. $\mathrm{Bu}$ yönleriyle bu çalışmanın literatüre katkı yapacağı düşünülmektedir. 
Çalışmada, sırayla önce çalışma konusu ve çalışmada kullanılan yöntemin uygulandıği çalışmalardan örnekler içeren literatür incelemesi verilmiş, takip eden aşamada çalışmada kullanılan FUCOM ve PROMETHEE yöntemlerinin işleyişi denklemler eşliğinde açıklanmıştır. Yöntemlerin açıklanmasının ardından uygulama kısmında analizler yapılmış, son olarak sonuçlar değerlendirilmiştir.

\section{Literatür İncelemesi}

Tablo 1'de hem çalışma konusu olan ticari araç seçimi ile ilgili yapılan çalışmalardan hem de FUCOM ve PROMETHEE yöntemlerinin kullanıldığı çalışmalardan örnekler verilmiştir. Bu çalışmanın literatürdeki çalışmalardan farkı, kriter ağırlıklarını sübjektif olarak belirlemede yeni bir yöntem olan FUCOM yönteminin kullanılmasıdır. Ayrıca bu çalışma peyzaj firması özelinde yapıldığı için, o firmanın belirlemiş olduğu 3 nakliye aracı kapsamında ve o firmaya özel kriterler baz alınarak çalışma yapılmıştır.

Tablo 1: Literatür taramas1

\begin{tabular}{|c|c|c|c|}
\hline $\begin{array}{c}\text { Çalışmanın } \\
\text { yazarı/yazarları }\end{array}$ & Çalışmanın konusu & \multicolumn{2}{|c|}{ Kullanılan yöntem/ler } \\
\hline \multicolumn{4}{|c|}{ FUCOM ile yapılan çalışma örnekleri } \\
\hline Ecer $(2021 a)$ & $\begin{array}{lrr}\text { Rüzgâr } & \text { çiftliği } & \text { yer } \\
\text { seçiminde } & \text { etkili } & \text { olan } \\
\text { kriterlerin } & & \text { önem } \\
\text { derecelerinin belirlenmesi }\end{array}$ & FUCOM & \\
\hline Ecer $(2021 b)$ & $\begin{array}{lr}\text { Bir otomobil yedek parça } \\
\text { firmasında } & \text { sürdürülebilir } \\
\text { tedarikçi } & \text { seçimi } \\
\text { uygulaması } & \\
\end{array}$ & FUCOM & \\
\hline Demir (2021) & $\begin{array}{l}\text { E-devlet web sitelerinin } \\
\text { değerlendirilmesinde } \\
\text { kullanılan kriterlerin } \\
\text { ağırlıklarının bulunması }\end{array}$ & \multicolumn{2}{|c|}{ FUCOM ve MAIRCA } \\
\hline Ayçin ve Aşan (2021) & $\begin{array}{l}\text { İş zekâsı seçiminde etkili } \\
\text { olan } \\
\text { ağırlıklarının bulunması }\end{array}$ & \multicolumn{2}{|c|}{ Bulanık FUCOM } \\
\hline Demir ve Bircan (2020) & $\begin{array}{l}\text { Özel okul seçiminde etkili } \\
\text { olan } \\
\text { ağırlıklarının bulunması }\end{array}$ & \multicolumn{2}{|l|}{ FUCOM } \\
\hline Sofuoğlu (2020) & $\begin{array}{l}\text { İş parçası için geleneksel } \\
\text { olmayan üretim } \\
\text { yöntemlerinden } \\
\text { uygununun belirlenmesi }\end{array}$ & \multicolumn{2}{|c|}{ BWM ve FUCOM } \\
\hline Stevic ve Brkovic (2020) & $\begin{array}{lr}\text { Uluslararası } & \text { bir } \\
\text { taşımacılık } & \text { şirketinde } \\
\text { çalışan } & \text { sürücülerin } \\
\text { performanslarının } \\
\text { değerlendirilmesi }\end{array}$ & $\begin{array}{l}\text { FUCOM, } \\
\text { TOPSIS ve } \\
\text { WASPAS }\end{array}$ & $\begin{array}{l}\text { Bulanık } \\
\text { Bulanık }\end{array}$ \\
\hline
\end{tabular}


FUCOM ve PROMETHEE Yöntemleri ile Ticari Araç Seçimi: Peyzaj Firmasında Bir

Tablo 1: Literatür taramas1

\begin{tabular}{|c|c|c|}
\hline $\begin{array}{c}\text { Çalışmanın } \\
\text { yazarı/yazarları }\end{array}$ & Çalışmanın konusu & Kullanılan yöntem/ler \\
\hline Milosavljević vd. (2020) & $\begin{array}{lr}\text { Radyo } & \text { Frekansı } \\
\text { Tanımlama } & \text { (RFID) } \\
\text { teknolojisi cihazlarının } \\
\text { Sirp demiryollarındaki } \\
\text { konumlarının } \\
\text { belirlenmesi. }\end{array}$ & $\begin{array}{l}\text { FUCOM-TOPSIS ve } \\
\text { Bulanık mantık }\end{array}$ \\
\hline Nunic ve Stevic (2019) & $\begin{array}{l}\text { Elektrikli araçların } \\
\text { değerlendirilmesi ve } \\
\text { optimum olanının } \\
\text { belirlenmesi }\end{array}$ & FUCOM ve EDAS \\
\hline Erceg vd. (2019) & $\begin{array}{l}\text { ABC analizi, FUCOM ve } \\
\text { CoCoSo yöntemlerinin } \\
\text { birlikte kullanımıla yeni } \\
\text { bir stok yönetim modeli } \\
\text { uygulaması }\end{array}$ & $\begin{array}{l}\text { ABC analizi, FUCOM ve } \\
\text { CoCoSo }\end{array}$ \\
\hline $\begin{array}{l}\text { Badi ve Abdulshahed } \\
(2019)\end{array}$ & $\begin{array}{lr}\text { Libya } & \text { havayolu } \\
\text { firmalarının } & \text { performans } \\
\text { ölçümü } & \\
\end{array}$ & AHP ve FUCOM \\
\hline Ibrahimovic vd. (2019) & $\begin{array}{l}\text { Uluslararası bir nakliye } \\
\text { şirketinde ulaşım aracı } \\
\text { seçimi }\end{array}$ & FUCOM ve MABAC \\
\hline Fazlollahtabar vd. (2019) & $\begin{array}{l}\text { Bir depo için forklift } \\
\text { seçimi }\end{array}$ & FUCOM ve WASPAS \\
\hline Adnan vd. (2019) & $\begin{array}{l}\text { Uluslararası taşımacılıkta } \\
\text { kullanılan en iyi ulaşım } \\
\text { aracı seçimi. }\end{array}$ & FUCOM ve ARAS \\
\hline Prentkovskis vd. (2018) & $\begin{array}{l}\text { Lojistik sektöründe bir } \\
\text { ekspress posta firmasında } \\
\text { hizmet kalitesinin } \\
\text { ölçülmesi }\end{array}$ & $\begin{array}{l}\text { Delphi-FUCOM- } \\
\text { SERVQUAL model }\end{array}$ \\
\hline \multicolumn{3}{|c|}{ PROMETHEE ile yapılan çalışma örnekleri } \\
\hline Korkusuz vd. (2020) & $\begin{array}{l}27 \text { hastanenin iş sağlığı } \\
\text { güvenliği performansının } \\
\text { karşılaştırılması }\end{array}$ & $\begin{array}{l}\text { AHP, PROMETHEE ve } \\
\text { GRA }\end{array}$ \\
\hline Sarısoy (2019) & $\begin{array}{l}\text { BIST 2010-2015 verileri } \\
\text { ile portföy oluşturulmas1 }\end{array}$ & PROMETHEE \\
\hline Özder vd. (2019) & $\begin{array}{l}\text { Bir yüksek öğretim } \\
\text { kurumunun endüstri } \\
\text { mühendisliği bölümünde } \\
\text { yapılacak araştırma } \\
\text { projesi için en uygun }\end{array}$ & AHP ve PROMETHEE \\
\hline
\end{tabular}


Tablo 1: Literatür taramas1

\begin{tabular}{|c|c|c|}
\hline $\begin{array}{c}\text { Çalışmanın } \\
\text { yazarı/yazarları }\end{array}$ & Çalıșmanın konusu & Kullanılan yöntem/ler \\
\hline & araştırmacı seçimi & \\
\hline Metin ve Küçükbay (2019) & $\begin{array}{l}\text { Firmaların ihracat } \\
\text { finansmanında önem } \\
\text { verdikleri kriterlerin ve } \\
\text { ihracat finansman } \\
\text { yöntemlerinin sıralanması }\end{array}$ & PROMETHEE \\
\hline Onan (2014) & $\begin{array}{l}\text { İzmir'de satışa sunulan } \\
\text { konut projelerinin } \\
\text { değerlendirilmesi }\end{array}$ & $\begin{array}{l}\text { PROMETHEE ve GAIA } \\
\text { (Geometrical Analysis } \\
\text { for Interactive Aid) } \\
\text { düzlemi gösterimi }\end{array}$ \\
\hline Özdağoğlu (2013) & $\begin{array}{l}\text { Üretim işletmelerindeki } \\
\text { lazer kesme } \\
\text { makinelerinin } \\
\text { karş1laştırılması }\end{array}$ & PROMETHEE \\
\hline $\begin{array}{l}\text { Schwartz ve Göthner } \\
(2009)\end{array}$ & $\begin{array}{l}\text { Almanya'daki iş } \\
\text { inkübatörlerinin } \\
\text { değerlendirilmesi }\end{array}$ & PROMETHEE \\
\hline Baourakis vd. (2002) & $\begin{array}{l}\text { Tarımsal gıda üretimi ve } \\
\text { pazarlaması alanında } \\
\text { faaliyet gösteren } \\
\text { şirketlerin finansal } \\
\text { kriterlere göre } \\
\text { değerlendirilmesi }\end{array}$ & PROMETHEE II \\
\hline \multicolumn{3}{|c|}{$\begin{array}{c}\text { Ticari araç, otomobil, nakliye aracı vb. seçimi konularında yapılan çalışma } \\
\text { örnekleri }\end{array}$} \\
\hline Sonar ve Kulkarni (2021) & $\begin{array}{l}\text { Sera gazı emisyonlarının } \\
\text { azaltılmasında hayati bir } \\
\text { rol oynayarak küresel } \\
\text { 1sınma sorununun } \\
\text { azalmasına fayda sağlayan } \\
\text { ve ülkelerin sürdürülebilir } \\
\text { kalkınmasına katkıda } \\
\text { bulunan elektrikli araç } \\
\text { seçimine yönelik } \\
\text { uygulama }\end{array}$ & AHP ve MABAC \\
\hline Malli vd. (2021) & $\begin{array}{l}\text { Maden ocaklarında } \\
\text { taşımacılıkta kullanılan en } \\
\text { uygun kamyonun seçimi }\end{array}$ & $\begin{array}{l}\text { AHP ve Bulanık WSM } \\
\text { (Weight Sum Method) }\end{array}$ \\
\hline Alizadeh and Safi (2020) & $\begin{array}{l}\text { Tahran'da yolculara daha } \\
\text { iyi hizmet sunabilmek } \\
\text { adına otobüs filosunun }\end{array}$ & $\begin{array}{l}\text { Veri Zarflama Analizi ve } \\
\text { Veri Madenciliği }\end{array}$ \\
\hline
\end{tabular}


FUCOM ve PROMETHEE Yöntemleri ile Ticari Araç Seçimi: Peyzaj Firmasında Bir

Tablo 1: Literatür taramas1

\begin{tabular}{|c|c|c|}
\hline $\begin{array}{c}\text { Çalışmanın } \\
\text { yazarı/yazarları }\end{array}$ & Çalışmanın konusu & Kullanılan yöntem/ler \\
\hline & $\begin{array}{ll}\text { performans } & \text { ve } \\
\text { verimliliğinin } & \\
\text { değerlendirilmesi } & \\
\end{array}$ & \\
\hline Demirci, A. (2020) & Nakliye aracı seçimi & TOPSIS ve VIKOR \\
\hline Biscas vd (2020) & Ticari binek araç seçimi & CRITIC ve CoCoSo \\
\hline Keleş (2019) & $\begin{array}{l}\text { B sınıfi otomobil } \\
\text { markalarının sıralanması }\end{array}$ & Entropi ve ELECTRE III \\
\hline Ic ve Şimşek (2019) & $\begin{array}{l}\text { Artan CO2 salınımı ve } \\
\text { ciddi enerji sıkıntısı } \\
\text { sonucunda çevre } \\
\text { kirliliğini azaltıcı etkisi } \\
\text { olan hibrit elektrikli } \\
\text { otomobil seçim problemi } \\
\text { uygulaması }\end{array}$ & Taguchi ve TOPSIS \\
\hline Ulutaş ve Yürüyen (2019) & Nakliye kamyonu seçimi & $\begin{array}{l}\text { PSI, ARAS, OCRA, } \\
\text { MOORA }\end{array}$ \\
\hline Süt vd. (2019) & $\begin{array}{l}\text { Kırıkkale } \quad \text { Üniversitesi } \\
\text { kampüsünde } \\
\text { üzullanılmak }\end{array}$ & AHP ve TOPSIS \\
\hline Anbarc1 vd . (2017) & $\begin{array}{l}\text { İnşaat } \quad \text { işlerinde } \\
\text { kullanılmak üzere kamyon } \\
\text { seçimi }\end{array}$ & MOORA \\
\hline Doğan vd. (2017) & $\begin{array}{l}\text { Lojistik sektöründe ağır } \\
\text { ticari araç seçimi } \\
\text { uygulaması }\end{array}$ & COPRAS-G \\
\hline Canbazoğlu vd. (2017) & $\begin{array}{l}\text { Ticari taksi } \\
\text { alternatiflerinin } \\
\text { siralanması }\end{array}$ & $\begin{array}{l}\text { Analitik Hiyerarşi Süreci } \\
\text { (AHS) ve MOORA }\end{array}$ \\
\hline $\begin{array}{l}\text { Chakraborty ve Prasad } \\
(2016)\end{array}$ & $\begin{array}{l}\text { Üretim sistemlerinde } \\
\text { etkinliğe direkt etkisi olan } \\
\text { istifleme taşıma işlerini } \\
\text { yapan endüstriyel forklift } \\
\text { seçimi }\end{array}$ & $\begin{array}{l}\text { Kalite } \\
\text { Göçerimi }\end{array}$ \\
\hline Adheesh vd. (2016) & $\begin{array}{l}\text { Hindistan, Bengaluru'da } \\
\text { hava kirliliğini azaltmak } \\
\text { için dizel otobüsler ve } \\
\text { elektrikli otobüslerin } \\
\text { karşılaştırılması }\end{array}$ & $\begin{array}{l}\text { Teknik bilgiler açısından } \\
\text { karşılaştırmalı analiz }\end{array}$ \\
\hline Kabak ve Uyar (2013) & $\begin{array}{l}\text { Ulaştırma sektöründe } \\
\text { faaliyet gösteren bir firma }\end{array}$ & AAS ve PROMETHEE \\
\hline
\end{tabular}


Tablo 1: Literatür taramas1

\begin{tabular}{|l|l|l|}
\hline \multicolumn{1}{|c|}{$\begin{array}{c}\text { Çalışmanın } \\
\text { yazarı/yazarları }\end{array}$} & \multicolumn{1}{c|}{ Çalışmanın konusu } & \multicolumn{1}{c|}{ Kullanılan yöntem/ler } \\
\hline & $\begin{array}{l}\text { için yük taşıma işi için } \\
\text { ağır ticari araç seçimi }\end{array}$ & \\
\hline Baykasoğlu vd. (2013) & $\begin{array}{l}\text { Bir kara taşımacılık } \\
\text { firması için en uygun } \\
\text { kamyon seçiminin } \\
\text { yapılması }\end{array}$ & $\begin{array}{l}\text { Bulanık DEMATEL ve } \\
\text { Bulanık hiyerarşik } \\
\text { TOPSIS }\end{array}$ \\
\hline Soba (2012) & $\begin{array}{l}\text { En uygun panelvan } \\
\text { otomobil seçimi. }\end{array}$ & PROMETHEE \\
\hline & $\begin{array}{l}\text { Küçük ölçekli bir işletme } \\
\text { için hafif ticari araç } \\
\text { seçimi }\end{array}$ & Analitik Ağ Süreci (AAS) \\
\hline Özbek (2012) & $\begin{array}{l}\text { Belediye için toplu } \\
\text { taşımada kullanılmak } \\
\text { üzere otobüs seçimi }\end{array}$ & Bulanık AHP \\
\hline Şengül vd. (2012) & $\begin{array}{l}\text { En uygun otomobil } \\
\text { seçimi }\end{array}$ & Bulanık PROMETHEE \\
\hline Ballı vd. (2007) & \multicolumn{2}{|l}{}
\end{tabular}

\section{FUCOM Yöntemi}

FUCOM (Full Consistency Method) bir seçim probleminde etkisi olan kriterlerin ağırlıklarını belirlemek amacıyla kullanılabilecek yöntemlerdendir. FUCOM kriterler arasında karşılaştırmalar yaparak değerlendirme yapmakta ve kriter sayısının bir eksiği kadar karşılaştırma yeterli olduğu için tercih edilmektedir. Yöntemin işleyişi aşağıda sunulmuştur (Pamucar vd., 2018, 5-7).

Öncelikle uzman görüşlerinden yararlanılarak problemin çözümünde dikkate alınması gereken kriterler belirlenir.

$$
c_{j}: j . \text { kriter } ; j=1,2,3, \ldots n
$$

Daha sonra bu kriterler en önemliden en önemsize doğru sıralanır. Sıralama işlemi Eşitlik 1'de gösterilmiştir.

$$
\begin{gathered}
c_{j(k)} \text { : önemliden önemsize stralanmış kriter; } k=1,2,3, \ldots n \\
c_{j(1)}>c_{j(2)}>c_{j(3)}>\cdots c_{j(k)}
\end{gathered}
$$

Bir sonraki aşamada her bir kriterin kendinden sonra gelen kritere göre üstünlüğü uzman tarafından belirtilir.

$$
\varphi_{\frac{k-1}{k}}: \text { kriterin kendinden sonraki kritere göre üstünlük değeri }
$$

Üstünlük değerleri kriter sayısının bir eksiği kadar olacaktır. Üstünlük değerleri kümesi Eşitlik 2'de gösterilmiştir. 


$$
\varphi=\left[\varphi_{\frac{1}{2}} ; \varphi_{\frac{2}{3}} ; \varphi_{\frac{3}{4}} ; \ldots ; \varphi_{\frac{k-1}{k}}\right]
$$

Belirtilen değerler kullanılarak bir doğrusal programlama modeli hazırlanır. $\mathrm{Bu}$ doğrusal programlama modelinin amaç fonksiyonu sapma değerinin en küçüklenmesi şeklindedir. Uzmanın belirttiği üstünlük değerleri ne kadar tutarlı ise sapma değeri o kadar küçük olur.

\section{$\chi$ : sapma değeri}

Kurulan doğrusal programlama modelinin amaç fonksiyonu Eşitlik 3'te gösterilmiştir.

$$
z_{\min }=\chi
$$

Amaç fonksiyonu tanımlandıktan sonra kısıtların yazılması gerekmektedir. FUCOM yöntemindeki kısıtlar üç ana kategoride incelenebilir. Birinci kısıt kategorisi her bir kriterin kendinden sonra gelen kritere göre üstünlüğü ile ilgili olarak yazılacaktır. Birinci kısıt kategorisi Eşitlik 4'te verilmiştir.

$$
\begin{aligned}
& w_{j(k)}: k . \text { kriterin a } \breve{g} \iota r l ı \breve{g} l \\
& \left|\frac{w_{j(k-1)}}{w_{j(k)}}-\varphi_{\frac{k-1}{k}}\right| \leq \chi
\end{aligned}
$$

$\mathrm{Bu}$ kategoride kriter sayısının bir eksiği kadar kısıt yazılmalıdır. İkinci kategori kısıtlar ise üstünlük değerlerinden türetilerek yazılmaktadır. $\mathrm{Bu}$ kategoride kriter sayısının iki eksiği kadar kısıt bulunmalıdır. İkinci kategori kısıt yapısı Eşitlik 5'te gösterilmiştir.

$$
\left|\frac{w_{j(k-2)}}{w_{j(k)}}-\left(\varphi_{\frac{k-2}{k-1}}\right)\left(\varphi_{\frac{k-1}{k}}\right)\right| \leq \chi
$$

Son kısıt ise ağırlık toplamlarının 1 değerine eşit olması için yazılmaktadır. Bu kısıtın yapısı Eşitlik 6'da gösterilmiştir.

$$
\sum_{j=1}^{n} w_{j}=1
$$

Son aşamada doğrusal programlama modellerinin genel yapısında bulunan negatif olmama koşulu eklenmelidir. Negatif olmama koşulu Eşitlik 7'de gösterilmiştir.

$$
w_{j} \geq 0, \forall j i c ̧ i n
$$

Kurulan doğrusal programlama modeli çözüldüğünde kriter ağırlıkları elde edilmiş olur.

\section{PROMETHEE Yöntemi}

PROMETHEE (The Preference Ranking Organization Method For Enrichment Evaluation) yöntemi ikili karşılaştırmalarda her bir değerlendirme kriterine özgü farklı fonksiyon tipleri kullanılarak alternatifler arasında seçim yapmaya imkan veren bir 
ÇKKV (Çok Kriterli Karar Verme) yöntemidir. Yöntemin işleyişi aşağıda denklemler eşliğinde verilmiştir (Behzadian vd., 2010).

İlk aşamada karar matrisi oluşturulur. Karar matrisi yapısı Eşitlik 8'de gösterilmiştir.

$$
\begin{gathered}
j: \text { kriter } ; j=1,2,3, \ldots, n \\
a, b, c, \ldots, m: \text { alternatifler }
\end{gathered}
$$

$x_{a j}:$ a alternatifinin $j$ kriteri açısından değeri

$$
\left[\begin{array}{cccc}
x_{a 1} & x_{a 2} & \cdots & x_{a n} \\
x_{b 1} & x_{b 2} & \cdots & x_{b n} \\
\cdots & \cdots & \ddots & \cdots \\
x_{m 1} & x_{m 2} & \cdots & x_{m n}
\end{array}\right]
$$

PROMETHEE yöntemine göre ikinci aşamada her bir kriter için uygun tercih fonksiyonu seçilir. Tercih fonksiyonlarının yapısı Tablo 2'de gösterilmiştir. Bu tercih fonksiyonu içindeki kıyaslama yapılan değer aynı kriter açısından alternatiflerin değerlerinin farkı alınarak bulunmaktadır. Fark işlemi Eşitlik 9'da gösterilmiştir.

$$
x_{j}(a, b)=\left\{\begin{array}{l}
\text { en büyük en iyi } \Rightarrow x_{a j}-x_{b j} \\
\text { en küçük en iyi } \Rightarrow x_{b j}-x_{a j}
\end{array}\right.
$$

Tablo 2: Tercih Fonksiyonları

\begin{tabular}{|l|l|c|}
\hline Fonksiyon Tipi & Parametreler & Fonksiyon Yapıs1 \\
\hline $\begin{array}{l}\text { Birinci Tip } \\
\text { (Olağan) }\end{array}$ & - & $P_{j}(a, b)=\left\{\begin{array}{l}x_{j}(a, b) \leq 0 \Rightarrow 0 \\
x_{j}(a, b)>0 \Rightarrow 1\end{array}\right.$ \\
\hline $\begin{array}{l}\text { İkinci Tip (U } \\
\text { Tipi) }\end{array}$ & $l$ & $P_{j}(a, b)=\left\{\begin{array}{l}x_{j}(a, b) \leq l \Rightarrow 0 \\
x_{j}(a, b)>l \Rightarrow 1\end{array}\right.$ \\
\hline $\begin{array}{l}\text { Üçüncü Tip (V } \\
\text { Tipi) }\end{array}$ & $m$ & $P_{j}(a, b)=\left\{\begin{array}{c}x_{j}(a, b) \leq 0 \Rightarrow 0 \\
0<x_{j}(a, b) \leq m \Rightarrow \frac{x}{m} \\
x_{j}(a, b)>m \Rightarrow 1\end{array}\right.$ \\
\hline $\begin{array}{l}\text { Dördüncü Tip } \\
\text { (Seviyeli) }\end{array}$ & $q, p$ & $P_{j}(a, b)=\left\{\begin{array}{c}x_{j}(a, b) \leq 0 \Rightarrow q \\
q<x_{j}(a, b) \leq q+p \Rightarrow \frac{1}{2} \\
x_{j}(a, b)>q+p \Rightarrow 1\end{array}\right.$ \\
\hline $\begin{array}{l}\text { Beşinci Tip } \\
\text { (Doğrusal) }\end{array}$ & $s, r$ & $P_{j}(a, b)=\left\{\begin{array}{c}x_{j}(a, b) \leq 0 \Rightarrow s \\
s<x_{j}(a, b) \leq s+r \Rightarrow \frac{x-s}{r} \\
x_{j}(a, b)>s+r \Rightarrow 1\end{array}\right.$ \\
\hline $\begin{array}{l}\text { Altınc1 Tip } \\
\text { (Gaussian) }\end{array}$ & $\sigma$ & $P_{j}(a, b)=\left\{\begin{array}{c}x_{j}(a, b) \leq 0 \Rightarrow 0 \\
x_{j}(a, b)>0 \Rightarrow 1-e\end{array}\left(-\frac{x^{2}}{2 \sigma^{2}}\right)\right.$ \\
\hline
\end{tabular}


Tablo 2'de yer alan uygun tercih fonksiyonuna göre her bir alternatif çifti için tercih değerleri hesaplanır. Bu değerler yardımıyla her bir alternatif çifti için tercih indeksleri hesaplanır. Tercih indeksi işlemi için öncelikle kriter ağırlıklarına ihtiyaç bulunmaktadır. kriter ağırlıklarını toplamı Eşitlik 10'daki şartı sağlamalıdır.

$$
w_{j}: j \text { kriterinin } a \breve{g} \iota r l ı \breve{g} \iota
$$

$$
\sum_{j=1}^{n} w_{j}=1
$$

Tablo 2'deki uygun fonksiyon yardımıyla bulunan değerler ve kriter ağırlıkları kullanılarak tercih indeksinin hesaplanması Eşitlik 11'de gösterilmiştir.

$$
\begin{gathered}
\pi(a, b): \text { a alternatifin } b \text { alternatifine tercih indeksi } \\
\pi(a, b)=\sum_{j=1}^{n}\left\{w_{j}\left[P_{j}(a, b)\right]\right\}
\end{gathered}
$$

İzleyen adımda her bir alternatif için pozitif üstünlük değeri Eşitlik 12 kullanılarak hesaplanır.

$$
\begin{aligned}
& \Phi^{+}(a) \text { : a alternatifinin pozitif üstünlük değeri } \\
& \Phi^{+}(a)=\frac{\pi(a, b)+\pi(a, c)+\pi(a, d)+\cdots+\pi(a, m)}{m-1} ; \forall a, b, c, \ldots, m i c ̧ i n
\end{aligned}
$$

Daha sonra her alternatif için negatif üstünlük değeri Eşitlik 13 kullanılarak hesaplanır.

$$
\begin{aligned}
& \Phi^{-}(a) \text { : a alternatifinin ne gatif üstünlük değeri } \\
& \Phi^{-}(a)=\frac{\pi(b, a)+\pi(c, a)+\pi(d, a)+\cdots+\pi(m, a)}{m-1} ; \forall a, b, c, \ldots, m i c ̧ i n
\end{aligned}
$$

İzleyen adımda PROMETHEE I ile kısmi öncelikler belirlenir. "a" alternatifinin, "b" alternatifine tercih edilebilmesi için Eşitlik 14'teki durumlardan birini sağlamalıdır.

$$
\left.\begin{array}{l}
\Phi^{+}(a)>\Phi^{+}(b) \wedge \Phi^{-}(a)<\Phi^{-}(b) \\
\Phi^{+}(a)>\Phi^{+}(b) \wedge \Phi^{-}(a)=\Phi^{-}(b) \\
\Phi^{+}(a)=\Phi^{+}(b) \wedge \Phi^{-}(a)<\Phi^{-}(b)
\end{array}\right\}
$$

Eşitlik 15 'teki durumun oluşması halinde alternatifler birbirinden farksızdır.

$$
\Phi^{+}(a)=\Phi^{+}(b) \wedge \Phi^{-}(a)=\Phi^{-}(b)
$$

Eşitlik 16'daki durumlardan birinin gerçekleşmesi halinde alternatifler birbirleri ile karşılaştırılamaz.

$$
\left.\begin{array}{l}
\Phi^{+}(a)>\Phi^{+}(b) \wedge \Phi^{-}(a)>\Phi^{-}(b) \\
\Phi^{+}(a)<\Phi^{+}(b) \wedge \Phi^{-}(a)<\Phi^{-}(b)
\end{array}\right\}
$$

Son aşamada PROMETHEE II ile tam öncelikler hesaplanır. Her bir alternatif için tam öncelikler Eşitlik 17 yardımıyla hesaplanır.

$$
\Phi(a)=\Phi^{+}(a)-\Phi^{-}(a) ; \forall a, b, c, \ldots, m i c ̧ i n
$$




\section{Așkın ÖZDAĞOĞLU \\ 242 Murat Kemal KELES Volkan GENC}

Tam önceliklere göre alternatiflerin karşılaştırılması Eşitlik 18 kullanılarak yapilabilir.

$$
\left\{\begin{array}{c}
\Phi(a)>\Phi(b) \Rightarrow a \text { üstün } b \\
\Phi(a)=\Phi(b) \Rightarrow a \text { farksız } b
\end{array}\right.
$$

\section{Uygulama}

Değerlendirme çalışmalarının ilk aşamasında, sürücü kurslarında eğitmen olarak görev yapan ve vasitalar konusunda bilgi ve yetkinliğe sahip uzman kişilerle görüşme yapılmıştır. Ticari araç seçiminde dikkate alınması gereken kriterler, bu kriterlerin ölçüm birimleri ve ideal durumları Tablo 3 'te gösterilmiştir.

Tablo 3: Kriter Bilgileri

\begin{tabular}{|l|l|l|c|}
\hline Kriter Kodu & \multicolumn{1}{|c|}{ Kriter Adı } & \multicolumn{1}{|c|}{ Ölçüm Birimi } & İdeal Durum \\
\hline Kriter 1 & Motor Tork & Newtonmetre & $\begin{array}{c}\text { En Büyük En } \\
\text { İyi }\end{array}$ \\
\hline Kriter 2 & $\begin{array}{l}\text { Servis Yedek Parça } \\
\text { Yaygınlığ1 }\end{array}$ & $\begin{array}{l}0-100 \text { Değerlendirme } \\
\text { Puanı }\end{array}$ & $\begin{array}{c}\text { En Büyük En } \\
\text { İyi }\end{array}$ \\
\hline Kriter 3 & Dönüş Çap1 & Metre & $\begin{array}{c}\text { En Küçük En } \\
\text { İyi }\end{array}$ \\
\hline Kriter 4 & Istihap Haddi & Kilogram (Kasası) & $\begin{array}{c}\text { En Büyük En } \\
\text { İyi }\end{array}$ \\
\hline
\end{tabular}

Motor tork değeri, bir aracın motorundan, tekerleklerine gönderilen gücü yani ilgili motorun döndürme gücünü temsil eder. Döndürme momenti olarak da adlandırılan tork, Newtonmetre cinsinden Nm birimi ile ifade edilmektedir. Eğer bir aracın çekiş gücü iyi ise, bu tork değerinin yüksek olmasından kaynaklanır. Tork kuvveti ne kadar yüksek olursa aracın çekiş gücü ve zorlu yükler altında gidişi o kadar iyi olmaktadır (Kutluay, 2017). Bu sayede tork değeri yüksek olan bir motora sahip araç ağır yükleri kolayca çekebilir ve zorlu yol koşullarından (dik rampalar vb.) etkilenmeden sürücüsüne rahat kullanım sunar (daha az vites değiştirme, daha düşük yakıt tüketimi vb.). Eğer motor tork değeri düşük olursa bir araçta, istihap haddi ne kadar yüksek olursa olsun motor ağır yükleri çekmekte zorlanacağından hem konfor açısından hem tüketim açısından hem de motor hareketli parçalarının zorlanarak yıpranması açısından bir çok sorun ortaya çıkacaktır. Bu yüzden, ticari araç seçiminde motor tork değeri ana kriterlerden birini oluşturmaktadır.

Bir diğer önemli kriter ise, servis ve yedek parça yaygınlığıdır. Özellikle bir ticari araç seçiminde en önemli kriterlerden biri olmaktadır. Çünkü; araç arızalandığında veya herhangi bir kazaya karıștığında bir işletme için en kısa sürede servis yedek parça temini sağlanıp aracın günlük iş programına dahil edilmesi elzemdir. Servis ve yedek parça hizmetleri, kullanıcının aracını kullanım ömrü boyunca herhangi bir sekteye uğramadan kullanmasını sağlar. Bir araç satın alındığı tarihten itibaren kullanım ömrü boyunca uzun vadede sürekli servis ve yedek parça teminine ihtiyaç duyacaktır. Bu yönüyle yaygın yedek parça ve servis ağı satın alım noktasında kilit bileşenlerden birini oluşturmaktadır 
(Korkmaz, 2001). Aracın servis ve yedek parça ağının yetersiz olması servis dışı olduğu günlerin artmasına ve bu yüzden maliyetlerin artmasına ve zamanında teslim edilemeyen siparişler dolayısı ile müşteri kaybına bile neden olabilmektedir.

Başka bir önemli kriter ise dönüş çapıdır. Araçları değerlendirirken özellikle şehir içi kullanım kolaylığının sağlanması noktasında çok önemli bir kriter olmaktadır. En basit tabirle, ön tekerleklerin sağa ve sola en fazla ne kadar açılabildiğini ve bu sayede aracın üzerinde dönebileceği en küçük çaplı çemberi ifade eder. Aracın dönüş çapı ne kadar küçükse, o kadar iyidir. Özellikle dar alanlarda manevra kolaylığı açısından ciddi bir avantaj sağlamaktadır (Falchenko, 2020). Şehir içinde nakliye faaliyetlerinde kullanılacak ticari bir aracın seçiminde dönüş çapı en küçük olan alternatifin seçilmesi, şehir içerisinde sürücüye kullanım kolaylığı ve konfor artışı sağlamaktadır. Örneğin; dönüş çapı yüksek bir araç dar bir alanda iki manevrada istenilen konuma gelebilmekte iken, dönüş çapı düşük bir araç tek manevrada istenilen konuma gelebilmektedir.

Son kriter ise istihap haddidir. İstihap haddi ise aracın taşıyabileceği maksimum yük kapasitesini ifade etmektedir. Kamyonet "Azami yüklü ă̆ırlığı 3500 kilogramı geçmeyen ve yük taşımak için imal edilmiş motorlu araçtır" (Dost vd., 2016: XV). Karayolları trafik yönetmeliğinde de kamyonetlerin azami yüklü ağırlığg 3,5 ton ile sınırlandırıldığı belirtilmektedir. İlgili yönetmelikte karayollarında seyreden tüm araçlara ait yüklü ve yüksüz olarak karayolu yapısına zarar vermeden güvenle seyredebilecekleri ağırlıklar, taşıma sınırları belirtilmiştir (Karayolları Trafik Yönetmeliği). Araçların Karayolları trafik yönetmeliğinde belirtilen taşıma sınırı değerinin yani azami yüklü ağırlığının veya izin verilen azami yüklü ağırlığın aşılması gibi durumlar kanunen yasaklanmıştır (Karayolları Trafik Kanunu, 1983). Aracın yüksüz ağırlığı ne kadar düşük olursa, 3,5 ton sınırları dahilinde taşıyabileceği yük o kadar fazla olacaktır. Ticari araç seçiminde dikkate alınması gereken tüm bu kriterler, peyzaj firması içinde nakliye amaçlı alternatiflerin belirlenmesinde önemlidir. Amaçlar doğrultusunda kullanım yönlü maksimum verimin alınması noktasında alternatifler arasında seçim yaparken temel belirleyici unsurları oluşturmaktadır.

Kriterlerin belirlenmesinin ardından peyzaj firması açısından ne kadar önemli olduklarını belirlemek üzere FUCOM yöntemi ile değerlendirmeler yapılmıştır. Elde edilen cevaplar 1şığında hazırlanan doğrusal programlama modeli Tablo 4'te gösterilmiştir.

Tablo 4: Doğrusal Programlama Modeli

$$
\begin{gathered}
z_{\min }=\chi \\
\left|w_{2}-(1,45) w_{1}\right| \leq \xi \\
\left|w_{1}-(1,35) w_{4}\right| \leq \xi \\
\left|w_{4}-(1,20) w_{3}\right| \leq \xi \\
\left|w_{2}-(1,958) w_{4}\right| \leq \xi \\
\left|w_{1}-(1,620) w_{3}\right| \leq \xi \\
w_{1}+w_{2}+w_{3}+w_{4}=1 \\
w_{1} \geq 0 \\
w_{2} \geq 0 \\
w_{3} \geq 0
\end{gathered}
$$




\section{Așkın ÖZDAĞOĞLU \\ 244 Murat Kemal KELES Volkan GENC}

$$
w_{4} \geq 0
$$

Kurulan doğrusal programlama modeli Lingo yazılımı ile çözülmüştür. Bu amaçla Lingo içinde hazırlanan model Tablo 5 'te verilmiştir.

Tablo 5: Kodlar

\begin{tabular}{|c|}
\hline $\begin{array}{l}\min =\mathrm{sapma} \\
@ \mathrm{abs}\left(\mathrm{w} 2-1.45^{*} \mathrm{w} 1\right)<=\mathrm{sapma} \\
@ \mathrm{abs}\left(\mathrm{w} 1-1.35^{*} \mathrm{w} 4\right)<=\mathrm{sapma} \\
@ \mathrm{abs}\left(\mathrm{w} 4-1.20^{*} \mathrm{w} 3\right)<=\mathrm{sapma} \\
@ \mathrm{abs}\left(\mathrm{w} 2-1.958^{*} \mathrm{w} 4\right)<=\mathrm{sapma} \\
@ \mathrm{abs}(\mathrm{w} 1-1.62 * \mathrm{w} 3)<=\mathrm{sapma} \\
\mathrm{w} 1+\mathrm{w} 2+\mathrm{w} 3+\mathrm{w} 4=1 ;\end{array}$ \\
\hline
\end{tabular}

Kriter ağırlıkları Tablo 6'da gösterilmiştir.

Tablo 6: Kriter Ağırlıkları

\begin{tabular}{|c|c|}
\hline$\chi$ & 0,000282 \\
\hline$w_{1}$ & 0,262600 \\
\hline$w_{2}$ & 0,380798 \\
\hline$w_{3}$ & 0,162105 \\
\hline$w_{4}$ & 0,194498 \\
\hline
\end{tabular}

Tablo 6'da bahsedilen, W1; Motor tork değeri, W2; servis/yedek parça yaygınlı̆̆1, W3; Dönüş Çap1, W4; istihap haddini temsil etmektedir.

Tablo 6 değerlendirildiğinde servis yedek parça yaygınlığının en önemli kriter olarak birinci sırayı aldığı görülmektedir. Çünkü ticari bir işletmede, peyzaj firması da bu kapsam dahilinde değerlendirildiği için ticari amaçlı kullanılan bir araç herhangi bir arıza veya kazadan dolayı serviste beklediği her gün tamir ve yedek parça tedariki için geçen süre dahilinde zarar hanesine yazılan bir kalem olmaktadır. Bu yüzden aracın çalışır durumda tutulması servis ve yedek parça hizmetlerinin yaygın olması tek başına bütün diğer kriterlerden önemlidir. 2. Kriter ise motor tork değeri olarak karşımıza çıkmaktadır. Bir hafif ticari araç (kamyonet) ne kadar yüksek istihap haddine sahip olursa olsun motor tork değeri düşük bir alternatifte bir anlam ifade etmeyecektir. Çünkü, araç belirtilen istihap haddini taşımakta zorlanacaktır. 3. önemli kriter ise, istihap haddidir. Bir kamyonet yasal sınırlar dahilinde ne kadar fazla yük taşırsa o kadar nakliye maliyetlerinde azalma meydana gelecektir (yakıt, zaman, yıpranma vs.). Son olarak ise, dönüş çapı gelmektedir. Bu kriter şehir içinde dar alanlarda sürücüye konfor ve kullanım kolaylılığı sağlamaktadır.

Kriter ağırlıkları bulunduktan sonra ticari araç alternatiflerinin verileri toplanmıştır. Oluşturulan karar matrisi Tablo 7'de verilmiştir. 
FUCOM ve PROMETHEE Yöntemleri ile Ticari Araç Seçimi: Peyzaj Firmasında Bir

Tablo 7: Karar Matrisi

\begin{tabular}{|l|r|r|r|r|}
\hline & Kriter 1 & Kriter 2 & Kriter 3 & Kriter 4 \\
\hline Alternatif a & 405 & 80 & 11,4 & 1633 \\
\hline Alternatif b & 350 & 90 & 11,0 & 1785 \\
\hline Alternatif c & 422 & 50 & 12,0 & 1710 \\
\hline
\end{tabular}

Tablo 7'deki karar matrisinde, alternatif a; Ford Transit'i (URL1), alternatif b; Fiat Ducato'yu (URL2), alternatif c ise; Hyundai H350'yi (URL3) kamyonet karoserinde temsil etmektedir. Bahse konu olan veriler, Ford, Fiat ve Hyundai ticari araçlar resmi web sitesinden ulaşılan teknik özellik broşüründen elde edilmiş olup üreticiler tarafından sunulan resmi verilerdir.

Alternatifler arasında tercih yapabilmek amacıyla PROMETHEE yöntemi için gereken karar matrisinin Tablo 6'daki gibi oluşturulmasının ardından Eşitlik 9'a göre fark değerleri hesaplanmıştır. Bulunan değerler Tablo 8'dedir.

Tablo 8: Fark Değerleri

\begin{tabular}{|r|r|r|r|r|}
\hline & $j=1$ & $j=2$ & $j=3$ & $j=4$ \\
\hline$x_{j}(a, b)$ & 55 & -10 & $-0,4$ & -152 \\
\hline$x_{j}(a, c)$ & -17 & 30 & 0,6 & -77 \\
\hline$x_{j}(b, a)$ & -55 & 10 & 0,4 & 152 \\
\hline$x_{j}(b, c)$ & -72 & 40 & 1,0 & 75 \\
\hline$x_{j}(c, a)$ & 17 & -30 & $-0,6$ & 77 \\
\hline$x_{j}(c, b)$ & 72 & -40 & $-1,0$ & -75 \\
\hline
\end{tabular}

Fark değerleri hesaplandıktan sonra uygun tercih fonksiyonu belirlenmiştir. Promethee yöntemi yapısı gereği karar alıcının bir değerlendirme kriterinde belli bir tercihi yapmasına olanak tanır ve tercih fonksiyonları sayesinde değerlendirme kriterini belirli bir aralık çerçevesinde sınırlamasına da olanak sağlayabilir.

Promethee yöntemi 6 farklı tipte tercih fonksiyonu üzerine şekillenmiştir. Bunlar sırası ile; birinci tip foksiyon; karar vericinin kesin bir tercihi bulunuyorsa kullanılır, ikinci tip tercih fonksiyonu; karar verici değerlendirme kriteri yönlü kendi atadığı bir değerin üstünde tercih yapmak istiyorsa kullanılır, üçüncü tip fonksiyon; karar verici değerlendirme kriteri yönlü tercihini ortalama üstü bir değerde yapmak istiyorsa kullanılır, dördüncü tip fonksiyon; karar verici değerlendirme kriteri yönlü tercihini belli bir aralık çevresinde sınırlayacaksa kullanılır. Beşinci tip; karar verici tercihini ortalama üstü değerlerden yana kullanacaksa kullanılır. Altıncı tip fonksiyon ise; eğer karar verici açısından değerlendirme kriteri yönlü standart sapma belirleyici olacaksa kullanılır.

$\mathrm{Bu}$ çalışmada birinci tip fonksiyon kullanılmıştır. Birinci tip fonksiyonun seçilmesinin nedeni; peyzaj sektörü açısından karar vermede ilgili kriterlerin herhangi bir sinırlamaya tabi tutulmamasıdır.

Tablo 2'deki uygun tercih fonksiyonuna göre her bir alternatif çifti için elde edilen değerler Tablo 9'da verilmiştir. 
Tablo 9: Tercih Değerleri

\begin{tabular}{|r|r|r|r|r|}
\hline & $j=1$ & $j=2$ & $j=3$ & $j=4$ \\
\hline$P_{j}(a, b)$ & 1 & 0 & 0 & 0 \\
\hline$P_{j}(a, c)$ & 0 & 1 & 1 & 0 \\
\hline$P_{j}(b, a)$ & 0 & 1 & 1 & 1 \\
\hline$P_{j}(b, c)$ & 0 & 1 & 1 & 1 \\
\hline$P_{j}(c, a)$ & 1 & 0 & 0 & 1 \\
\hline$P_{j}(c, b)$ & 1 & 0 & 0 & 0 \\
\hline
\end{tabular}

İzleyen aşamada Eşitlik 11 kullanılarak tercih indeksleri hesaplanmıştır. Tercih indekslerinin hesaplanmasında yetkililerin verdiği cevaplara göre FUCOM yöntemi sonucu elde edilen ve Tablo 6'da yer alan kriter ağırlıkları PROMETHEE sürecine entegre olmuştur. Tablo 6 ve Tablo 9'da yer alan değerler kullanılarak bulunan tercih indeksleri Tablo 10'da gösterilmiştir.

Tablo 10: Tercih İndeksleri

\begin{tabular}{|c|c|}
\hline$\pi(a, b)$ & 0,262600 \\
\hline$\pi(a, c)$ & 0,542903 \\
\hline$\pi(b, a)$ & 0,737400 \\
\hline$\pi(b, c)$ & 0,737400 \\
\hline$\pi(c, a)$ & 0,457097 \\
\hline$\pi(c, b)$ & 0,262600 \\
\hline
\end{tabular}

Ardından Eşitlik 12 ve Eşitlik 13 kullanılarak her bir alternatifin pozitif ve negatif üstünlük değerleri hesaplanmıştır. Bulunan değerler Tablo 11 'de verilmiştir.

Tablo 11: Pozitif ve Negatif Üstünlük Değerleri

\begin{tabular}{|c|c|c|c|}
\hline$\Phi^{+}(a)$ & 0,402751 & $\Phi^{-}(a)$ & 0,597249 \\
\hline$\Phi^{+}(b)$ & 0,737400 & $\Phi^{-}(b)$ & 0,262600 \\
\hline$\Phi^{+}(c)$ & 0,359849 & $\Phi^{-}(c)$ & 0,640151 \\
\hline
\end{tabular}

Tablo 11'deki değerler kullanılarak PROMETHEE I ile kısmi öncelikler belirlenir. Bu amaçla Eşitlik 14, Eşitlik 15 ve Eşitlik 16'daki durumlar her bir alternatif ikilisi için incelenmelidir. Tablo 10'daki değerlere göre aşağıdaki durum gerçekleşmekte ve buna göre tüm kriterler birarada incelendiğinde PROMETHEE I ile kısmi öncelikler açısından alternatiflerin sıralaması $b>a>c$ şeklinde olmaktadır. Kısmi öncelik sonuçlarına göre değerlendirmeler Tablo 12'de gösterilmiştir.

Tablo 12: PROMETHEE I Kısmi Öncelik Yorumları

\begin{tabular}{|c|c|}
\hline Kiyaslama & Anlam \\
\hline$\Phi^{+}(b)>\Phi^{+}(a) \wedge \Phi^{-}(b)<\Phi^{-}(a)$ & b üstün a \\
\hline$\Phi^{+}(b)>\Phi^{+}(c) \wedge \Phi^{-}(b)<\Phi^{-}(c)$ & b üstün c \\
\hline$\Phi^{+}(a)>\Phi^{+}(c) \wedge \Phi^{-}(a)<\Phi^{-}(c)$ & a üstün c \\
\hline
\end{tabular}

Son aşamada PROMETHEE II ile her alternatif için tam öncelikler Eşitlik 17 yardımıyla hesaplanır. Bulunan tam öncelik değerleri Tablo 13'te gösterilmiştir. 
Tablo 13: Tam Öncelik Değerleri

\begin{tabular}{|l|r|}
\hline$\Phi(a)$ & $-0,194498$ \\
\hline$\Phi(b)$ & 0,474800 \\
\hline$\Phi(c)$ & $-0,280303$ \\
\hline
\end{tabular}

Eşitlik 18 kullanılarak yapılan tam öncelik karşılaştırmaları Tablo 14'te verilmiştir.

Tablo 14: PROMETHEE II Tam Öncelik Yorumları

\begin{tabular}{|c|c|}
\hline Kıyaslama & Anlam \\
\hline$\Phi(b)>\Phi(a)$ & b üstün a \\
\hline$\Phi(b)>\Phi(c)$ & b üstün c \\
\hline$\Phi(a)>\Phi(c)$ & a üstün c \\
\hline
\end{tabular}

Tüm kriterler incelendiğinde; alternatif B'nin tüm diğer alternatiflerden üstün olduğu görülmektedir. Alternatif B'nin tüm diğer alternatiflerden üstün olmasının temel nedeni, servis ve yedek parça ağının yüksek oluşudur.

Alternatif B, temelde 2 Fransız markası ve 1 İtalyan markası tarafından ortak platformda ve ortak karoserde artı olarak yüksek yoğunluklu ortak parça kullanımı ile üretilmektedir. Ülkemizde bu markaların 3 farklı distiribütör ağı ile teknik servis ve yedek parça hizmetine olanak tanımasından dolayı bu sonuçla karşılaşmaktayız. Bir işletme bu 3 farklı distribitörden servis ve yedek parça temini yapabilir. Diğer alternatifler ise tek bir distribitör ağından bu hizmetleri sunmaktadır.

Yine alternatif B'nin sonuçlarına baktığımızda, 1'den fazla kriterde diğer alternatiflere üstünlük sağladığını görmekteyiz. Istihap haddi ve dönüş çapında da açık ara önde olması alternatif $B$ ile diğer alternatifler arasındaki makası açmaktadır. Tek başına bir kriter dahilinde sağlanan üstünlük karar verme noktasında bir işletme olarak peyzaj firmasının alternatifler arasında seçimi yapmasına yeterli dayanak oluşturamamaktadır. Örneğin; gerekli servis hizmeti sağlanamadıktan sonra, yüksek motor tork değerinin olması tek başına bir şey ifade edememektedir. Çünkü, bu aracı çalışır halde ve maksimum verimlilikte tutmak için servis desteği gerekecektir.

\section{Sonuç ve Değerlendirme}

Günümüz şartları, rekabeti firmalar açısından çok zorlu hali getirmiştir. Peyzaj firmaları da bu zorlu rekabet şartlarından etkilenmektedir. Şehirlerin monotonluğu, aşırı betonlaşma sonucu tıpkı griye boyanmış gibi bir yapıya bürünmeleri, insanları etkilemekte ve var olan mekanların üzerini sıkıcı bir örtü gibi örtmektedir. Bu tarz ortamları renklendirmek ve iç açıcı bir yapıya kavuşturmak için peyzaj firmalarına düşen görev büyüktür. Günümüzde oluşan yeni trend peyzaj firmalarına verilen önemi arttırmakta ve bu alanda çok sayıda yeni firmaların faaliyete başlamasına sebep olmaktadır. Şehirlerimizde ki sıkıșık trafik, yokuşlu yollar ve dar sokaklar peyzaj firmalarının hizmetini götürebilmesi açısından zorluklar yaratmaktadır. Halihazırda, tüm bu sorunlarla başa çıkılabilmesi açısından doğru aracın seçimi önemlidir. Yoğun trafik şartlarında ve yokuşlu yollarda sorun çıkarmayacak kadar güçlü, dar sokaklara kolaylıkla girebilecek kadar kıvrak ve mevzuatın izin vermiş olduğu maksimum yükü taşıyabilecek sağlam araçların seçimi işletme açısından önemlidir. 


\section{Așkın ÖZDAĞOĞLU \\ 248 Murat Kemal KELES Volkan GENC}

Her işletme kendi sektörü ve ihtiyaçları özelinde çeşitli araçlar kullanabilmektedir. $\mathrm{Bu}$ çalışmada, peyzaj sektöründe faaliyet gösteren bir firma için faaliyetleri açısından önem arz eden en uygun kamyonetin seçimi yapılmıştır. Kamyonet seçiminde, uygulamanın yapıldığı peyzaj firmasının belirlediği kriterlere göre firmanın ihtiyaçlarına ve taleplerine cevap verecek en uygun kamyonet belirlenmiştir.

Çalışmada FUCOM ve PROMETHEE yöntemi bütünleşik olarak kullanılmıştır. Elde edilen veriler dahilinde ortaya çıkan sonuçlara bakıldığında, tek bir kriterde ortaya çıkan başarılı sonuçların tek başına satın alma kararı verme üzerinde etkisi olamadığı görülmektedir. Örneğin yüksek motor tork değeri sunan bir alternatifin, eğer istihap haddi düşük ise, ticari yönlü fazla bir katkı sunamamaktadır veya yüksek tork değeri ve istihap haddini sunan bir alternatif yeterli servis ve yedek parça hizmetini sunamıyorsa yine bu yüksek değerler birşey ifade edememektedir. Çünkü ticari bir işletme olan peyzaj firması bu aracı kullanım ömrü boyunca kullanırken hem periyodik bakımlar yaptırmaya ihtiyaç duyacaktır hem de olası bir arıza veya kaza durumunda en kısa sürede yedek parça ve servis hizmetini alarak aracını en kısa zamanda günlük çalışma programına dahil etmek isteyecektir. Zaten kriter ağırlıklarına baktığımızda en önemli kriterin yedek parça ve servis yaygınlığı olduğu görülmektedir. Günlük çalışma programına dahil edilmede gecikme yaşanan her gün firmaya ekonomik olarak zarar doğuracaktır. Ticari aracın kullanım ömrü genel olarak on yılllk bir süreci ifade etmektedir ve bu süreçte yedek parça ve servis hizmetlerinin önemi kat ve kat artmaktadır. Bu yüzden alternatifler arasında seçim yaparken firma birden çok kriterde başarılı olan alternatifi tercih etmek zorundadir.

İlerleyen süreçte yapılacak çalışmalarda farklı sektörler için farklı ticari araç seçimi uygulamaları yapılabilir. Bu çalışmada ÇKKV yöntemlerinden FUCOM ve PROMETHEE kullanılmıştır. Ticari araç seçiminde yapılacak çalışmalarda kriter ağırlıklarııı bulunması ve alternatifler arasından yapılacak seçimlerde farklı ÇKKV yöntemleri de kullanılabilir.

\section{Kaynaklar}

Adheesh, S. R., Vasisht, M. S., \& Ramasesha, S. K. (2016). "Air-pollution and economics: diesel bus versus electric bus", Current Science, 858-862.

Adnan, M., Adin, R., Nunic, Z., Stevic, Z., \& Sremac, S. (2019). "Selection of transportation mean using integrated FUCOM-ARAS model". 12th International Conference of Iranian Operations Research Society, Mazandaran University of Science and Technology, Mizban International Hotel, Babolsar, Iran-1st and 2nd May 2019.

Alizadeh, S., and Safi, M., 2020. "A new model for efficiency evaluation of a bus fleet by window analysis in DEA and data mining", Transportation Planning and Technology, 43(1): 62-77. doi: 10.1080/03081060.2020.1701750.

Anbarcı, M., Öz, B., \& Giran, Ö. (2017). “İnşaat Yönetiminde Nakliye Aracı Seçiminde Moora Çok Ölçütlü Karar Verme Yöntemi ile Bir Uygulama”, Uluslararası Katılımlı 7. İnşaat Yönetimi Kongresi, Samsun, 149-154. 
Ayçin, E., \& Aşan, H. (2021). "İş zekası uygulamaları seçimindeki kriterlerin önem ağırlıklarının FUCOM yöntemi ile belirlenmesi”, KOCATEPEİIBFD, 23(2), 195 208. https://doi.org/10.33707/akuiibfd.903563.

Badi, I., \& Abdulshahed, A. (2019). "Ranking the Libyan Airlines by Using Full Consistency Method (Fucom) and Analytical Hierarchy Process (AHP)", Operational Research in Engineering Sciences: Theory and Applications, 2(1), 1-14. DOI: https://doi.org/10.31181/oresta1901001b.

Ballı, S., Karasulu, B., \& Korukoğlu, S. (2007). "En Uygun Otomobil Seçimi Problemi İçin Bir Bulanık Promethee Yöntemi Uygulaması”, Dokuz Eylül Üniversitesi İktisadi ve Ídari Bilimler Fakültesi Dergisi, 22(1), 139-147.

Baourakis, G., Doumpos, M., Kalogeras, N., \& Zopounidis, C. (2002). « Multicriteria analysis and assessment of financial viability of agribusinesses: The case of marketing co-operatives and juice-producing companies", Agribusiness: An International Journal, 18(4), 543-558.

Baykasoğlu, A., Kaplanoğlu, V., Durmuşoğlu, Z. D., \& Şahin, C. (2013). “Integrating fuzzy DEMATEL and fuzzy hierarchical TOPSIS methods for truck selection", Expert Systems with Applications, 40(3), 899-907. https://doi.org/10.1016/j.eswa.2012.05.046

Behzadian, M., Kazemzadeh, R. B., Albadvi, A., \& Aghdasi, M. (2010). "Promethee: A Comprehensive Literature Review on Methodologies and Applications", European Journal of Operational Research, 200, 198-215.

Biswas, T., Chatterjee, P., \& Choudhuri, B. (2020). "Selection of Commercially Available Alternative Passenger Vehicle in Automotive Environment", Operational Research in Engineering Sciences: Theory and Applications, 3(1), 16-27. DOI: https://doi: 10.31181/oresta200113b.

Byun, D. H. (2001). "The AHP approach for selecting an automobile purchase model". Information and Management, 38(5), 289-297. https://doi.org/10.1016/S03787206(00)00071-9.

Canbazoğlu, E., Ercan, U., \& Çetin, E. İ. (2018). “Ticari Taksi Araç Yenilemelerinde AHS ve MOORA Yöntemlerine Dayalı Karar Destek Mobil Uygulaması", Uluslararası İktisadi ve İdari Incelemeler Dergisi, UIIIIDD-IJEAS, 2018 (18. EYİ Özel Sayıs1), 117-134. DOI: 10.18092/ulikidince.354009.

Chakraborty, S., \& Prasad, K. (2016). “A QFD-based expert system for industrial truck selection in manufacturing organizations", Journal of Manufacturing Technology Management, 800-817.

Demir, G. (2021). "Evaluation of e-government websites with fuzzy FUCOM", International Journal of Economic and Administrative Academic Research, 1(2), 4153. https://orcid.org/0000-0002-3916-7639. 
Demir, G. \& Bircan, H. (2020). "Kriter Ağırlıklandırma Yöntemlerinden BWM ve FUCOM Yöntemlerinin Karşılaştırılması ve Bir Uygulama”, Cumhuriyet Üniversitesi Íktisadi ve İari Bilimler Dergisi, 21(2), 170-185. DOI: 10.37880/cumuiibf.616766

Demirci, A. (2020). "Nakliye Aracı Seçimi: Çok Kriterli Karar Verme Modeli Önerisi", Antalya Bilim Üniversitesi Uluslararast Sosyal Bilimler Dergisi, 1(1), 17-34.

Doğan, E. M., Eren, M., \& Çelik, K. (2017). "Lojistik Sektöründe Ağır Ticari Araç Seçimi Problemine Yönelik Copras-G Yöntemi ile Karar Verme", Afyon Kocatepe Üniversitesi Sosyal Bilimler Dergisi, 19(1), 153-178. DOI No:10.5578/jss.43422.

Dost, Y., Terzioğlu, Y., İlhan, B., Olgun, A., \& Aydoğan, Culha, Ü. (2016). "Karayollarında Ağır Taşıt Trafiğinin ve Yük Taşımacılığının Özellikleri ve Eğilimleri” - 2010-2011-2012-2013-2014 Etüt Sonuçları, Trafik Güvenliği Dairesi Başkanlığı Ulaşım Etütleri Şubesi Müdürlüğü, https://www.utikad.org.tr/images/BilgiBankasi/karayollarindaagirtasittrafigininveyu ktasimaciligininozellikleriveegilimleri20102014-9696.pdf, (07.07.2020).

Ecer, F. (2021a). "FUCOM sübjektif ağırlıklandırma yöntemi ile rüzgâr çiftliği yer seçimini etkileyen faktörlerin analizi”, Pamukkale Üniversitesi Mühendislik Bilimleri Dergisi, 27(1), 24-34. doi: 10.5505/pajes.2020.93271.

Ecer, F. (2021b). "Sürdürülebilir Tedarikçi Seçimi: FUCOM Sübjektif Ağırlıklandırma Yöntemi Temelli MAIRCA Yaklaşımı", Mehmet Akif Ersoy Üniversitesi İktisadi ve Idari Bilimler Fakültesi Dergisi, 8(1), 26-48. https://doi.org/10.30798/makuiibf.691693.

Erceg, Ž., Starčević, V., Pamučar, D., Mitrović, G., Stević, Ž., \& Žikić, S. (2019). “A New Model for Stock Management in Order to Rationalize Costs: ABC-FUCOMInterval Rough CoCoSo Model”, Symmetry, 11(12), 1527. https://doi.org/10.3390/sym11121527

Falchenko, A. (2020). “Dönüş Yarıçapı Otomobiller İçin Önemli Bir Parametredir”, https://avtotachki.com/tr/radius-povorota-vazhnyj-parametr-dlya-avtomobilej/, (18.10.2021).

Fazlollahtabar, H., Smailbašić, A., \& Stević, Ž. (2019). "FUCOM Method in Group Decision-Making: Selection of Forklift in A Warehouse. Decision Making: Applications in Management and Engineering", 2(1), 49-65. DOI: https://doi.org/10.31181/dmame1901065f

Ibrahimović, F. I., Kojić, S. L., Stević, Ž. R., \& Erceg, Ž. J. (2019). "Making An Investment Decision in A Transportation Company Using An Integrated FUCOMMABAC model”, Tehnika, 74(4), 577-584. DOI: 10.5937/tehnika1904577I.

Ic, Y. T., \& Şimşek, E. (2019). “Operating window perspective integrated TOPSIS approach for hybrid electrical automobile selection", SN Applied Sciences, 1(11), 111. 
Kabak, M., \& Uyar, Ö.O. (2013). "Lojistik Sektöründe Ağır Ticari Araç Seçimi Problemine Çok Ölçütlü Bir Yaklaşım”, Journal of the Faculty of Engineering \& Architecture of Gazi University, 28(1), 115-125

Karayolları Trafik Kanunu. (1983). 2918 Karayolları Trafik Kanunu, Kabul Tarihi: $13 / 10 / 1983$

Karayolları Trafik Yönetmeliği. 2918 sayılı Karayolları Trafik Kanunu uyarınca çıkartılan yönetmelik, https://www.mevzuat.gov.tr/File/GeneratePdf?mevzuatNo=8182\&mevzuatTur=Kur umVeKurulusYonetmeligi\&mevzuatTertip=5, (18.10.2021).

Keleş, M. K. (2019). "Entropi Temelli Electre III Yöntemi ile B Segmenti Otomobil Markalarının Siralanması”, Süleyman Demirel Üniversitesi Sosyal Bilimler Enstitüsü Dergisi, 2(33), 29-50.

Korkmaz, S., (2001). "Satış Sonrası Hizmetler ve Satış Sonrası Hizmetlerin Tüketiciler Açısından Değerlendirilmesi”, Mevzuat Dergisi, Yı1:4, s.42, ISSN 1306-0767.

Korkusuz, A.Y., İnan, U. H., Özdemir, Y., \& Başlıgil, H. (2020). "Entegre Çok Kriterli Karar Verme Yöntemleriyle Sağlı Sektöründe İş Sağlığı ve Güvenliği Performansının Ölçülmesi”, Journal of the Faculty of Engineering \& Architecture of Gazi University, 35(1), 81-96.

Kutluay, H. (2017). “Tork Nedir, Beygir Gücünden Farkı Nedir, Nasıl Hesaplanır?”, https://www.makaleler.com/tork-nedir-beygir-gucunden-farki-nedir-nasilhesaplanir , (18.10.2021).

Malli, T., Yetkin, M. E., \& Ozfirat, M. K. (2021). “Truck Selection with the Fuzzy-WSM Method in Transportation Systems of Open Pit Mines", Tehnički vjesnik, 28(1), 5864.

Metin, İ., \& Küçükbay, F. (2019). “İhracatta Finansman Kaynaklarının Değerlendirilmesine Yönelik Çok Kriterli Bir Yaklaşım: PROMETHEE Yöntemi”, Bingöl Üniversitesi Sosyal Bilimler Enstitüsü Dergisi, 9(18), 931-948, DOI: $10.29029 /$ busbed.565328.

Milosavljević M., Jeremić D., \& Milinković S. (2020). "Selection of the Best Location for RFID Wagon Monitoring Device on Serbian Railways Based on FUCOMTOPSIS Method and Fuzzy Set Theory", In: Popovic Z., Manakov A., Breskich V. (eds) VIII International Scientific Siberian Transport Forum. TransSiberia 2019. Advances in Intelligent Systems and Computing, vol 1115, 527-539. Springer, Cham. DOI: https://doi.org/10.1007/978-3-030-37916-2_51

Nunic, Z., \& Staevic, Z. (2019). “A Novel Integrated Multi-Criteria Decision-Making Model: FUCOM-EDAS-M", Conference: Innovation As An Initiator of The Development, at Belgrade, Serbia. 19-34. 
Onan, A. (2014). "PROMETHEE Siralama Yönteminin Konut Projelerinin Değerlendirilmesinde Kullanılması", Afyon Kocatepe Üniversitesi İktisadi ve İdari Bilimler Fakültesi Dergisi, 16(1), 17-28.

Özbek, A. (2012). "Küçük Ölçekli İşletme İçin Analitik Ağ Süreci ile Ticari Araç Seçimi”, Mesleki Bilimler Dergisi (MBD), 1(4), 32-52.

Özdağoğlu, A. (2013). "Üretim İşletmelerinde Lazer Kesme Makinelerinin PROMETHEE Yöntemi ile Karşılaştırılması”, Uluslararası Yönetim İktisat ve İşletme Dergisi, 9(19), 305-318. http://dx.doi.org/10.11122/ijmeb.2013.9.19.288

Özder, E. H., Bedir, N., \& Eren,T. (2019). "Yükseköğretimde Araştırmacı Seçiminde Çok Ölçütlü Karar Verme Yöntemlerinin Kullanılması: Bir İnceleme", Alanya Akademik Bakış, 3(1), 19-33.

Pamucar, D., Stevic, Ž., \& Sremac, S. (2018). "A New Model for Determining Weight Coefficients of Criteria in MCDM Models: Full Consistency Method (FUCOM)", Symmetry, 10(393), 1-22. doi:10.3390/sym10090393.

Prentkovskis, O., Erceg, Ž., Stević, Ž., Tanackov, I., Vasiljević, M., \& Gavranović, M. (2018). "A new methodology for improving service quality measurement: DelphiFUCOM-SERVQUAL model”, Symmetry, 10(12), 757. https://doi.org/10.3390/sym10120757

Sarısoy, S. N. (2019). "PROMETHEE Sıralama Yöntemi ile Portföy Oluşturma ve Borsa İstanbul'da 2010-2015 Yılları Arasında Bir Uygulama", Marmara Üniversitesi Sosyal Bilimler Enstitüsü İșletme Anabilim Dalı, Yüksek Lisans Tezi.

Schwartz, M., \& Göthner, M. (2009). "A multidimensional evaluation of the effectiveness of business incubators: an application of the PROMEHEE outranking method", Environment and Planning C: Government and Policy, 27(6), 1072-1087, https://doi.org/10.1068/c0897b.

Soba, M. (2012). "Promethee Yöntemi Kullanarak En Uygun Panelvan Otomobil Seçimi ve Bir Uygulama", Journal of Yaşar University, 28(7), 4708-4721.

Sofuoğlu, M. A. (2020). "Fuzzy applications of FUCOM method in manufacturing environment”, Politeknik Dergisi, 23(1), 189-195. DOI: 10.2339/politeknik.586036.

Sonar, H. C., \& Kulkarni, S. D. (2021). "An Integrated AHP-MABAC Approach for Electric Vehicle Selection", Research in Transportation Business \& Management, 100665. https://doi.org/10.1016/j.rtbm.2021.100665.

Stević, Ž., \& Brković, N. (2020). "A Novel Integrated FUCOM-MARCOS Model for Evaluation of Human Resources in a Transport Company", Logistics, 4(1), 4. doi:10.3390/logistics4010004.

Süt, N. İ., Hamurcu, M., \& Eren, T. (2019). "Kampüste Yeşil Ulaşım Uygulaması: Ring Araçlarının Seçimi için Bir Karar Verme Süreci”, Gazi Mühendislik Bilimleri Dergisi (GMBD), 5(1), 9-21 https://dx.doi.org/10.30855/gmbd.2019.01.02. 
Şengül, Ü., Eren, M., \& Eslamian, Shiraz, S. (2012). "Bulanık AHP İle Belediyelerin Toplu Taşıma Araç Seçimi”, Erciyes Üniversitesi İktisadi ve İdari Bilimler Fakültesi Dergisi, 40, 143-165.

Ulutaş, A., \& Yürüyen, A. A. (2019). "Nakliye Aracı Seçimi İçin Karşılaştırmalı Çalışma", II. International Conference on Empirical Economics and Social Science (ICEESS' 19). June 20-21-22, 2019 / Bandırma - Turkey, Bandırma Onyedi Eylul University, ISBN NU: 978-605-69052-6-1, Full Paper Proceeding, 861-868.

URL1, Yeni Ford Transit Kamyonet, "Teknik Özellik ve Donanım Tablosu", https://www.ford.com.tr/getmedia/ae095703-5583-4cf3-8783-

c6b5da794702/transit-kamyonet-teknikfoy-temmuz-2020.pdf.aspx, (20.07.2020).

URL2, Ducato Kamyonet, "Ducato Kamyonet, sınırsız kullanışlılığı, yapım kalitesi ve teknolojik yeniliklere ev sahipliği yapan tasarımıyla işinizi büyütmenizi vaat ediyor", https://www.fiatprofessional.com/content/dam/fiatprofessional/tr/brochure/DucatoK amyonet_Mayis_2020.pdf, (07.05.2020).

URL3, Hyundai H350 Kamyonet, "İhtiyacınız Olan Ne Varsa Hepsi Bir Arada", http://www.hyundai-ticariaraclar.com/images/pdf/H350-KAMYONET.pdf, (07.07.2020). 